\title{
Progression from Partial Response
}

National Cancer Institute

\section{Source}

National Cancer Institute. Progression from Partial Response. NCI Thesaurus. Code C123604.

Disease progression occurring after a partial response. 